\title{
KEMAMPUAN GURU BAHASA INDONESIA DALAM MEMBUAT SOAL TES BERBASIS HOTS (HIGHER ORDER THINKING SKILLS) DI SMP SEKECMATAN KARANGNUNGGAL
}

\author{
Deni Chandra ${ }^{1}$, Dedi Heryadi ${ }^{2}$ \\ Program Studi Pendidikan Bahasa Inggris \\ Fakultas Keguruan dan Ilmu Pendidikan \\ Universitas Perjuangan Tasikmalaya \\ Jl. Pembela Tanah Air (PETA) No. 177 Kahuripan Kota Tasikmalaya \\ denichandra@unper.ac.id
}

\begin{abstract}
ABSTRAK: Penelitian ini bertujuan untuk mendeskripsikan (1) kemampuan guru mata pelajaran Bahasa Indonesia dalam membuat soal tes berbasis Higher Order Thinking Skills (HOTS) tingkat SMP se-Kecamatan Karangnunggal Kabupaten Tasikmalaya dan (2) menganalisis kesesuaian soal tes yang dibuat oleh guru mata pelajaran Bahasa Indonesia ditinjau dari kriteria soal Higher Order Thinking Skills (HOTS). Penelitian ini dilaksanakan di tiga Sekolah Menengah Pertama (SMP) yang berada di Kecamatan Karangnunggal Kabupaten Tasikmalaya dengan menggunakan metode deskriptif kualitatif.Sumber data dalam penelitian ini adalah guru mata pelajaran Bahasa Indonesia yang secara keseluruhan berjumlah 7 orang. Sumber data dari SMP N 1 Karangnunggal sebanayak 2 orang, dari SMP Negeri 3 Karangnunggal sebanyak 2 orang dan dari SMP IT Karangnunggal sebanyak 3 orang. Data yang diperoleh berupa soal esai dan pilihan ganda yang dibuat oleh setiap responden.Pemerolehan data dalam penelitian ini menggunakan instrumen tes.Data tersebut dikaji dengan teknik analisis deskriptif. Hasil pengkajian pertama diperoleh kemampuan guru mata pelajaran Bahasa Indonesia dalam membuat soal tes berbasis HOTS dalam bentuk esai maupun pilihan ganda masih rendah. Hal tersebut terbukti dari jumlah keseluruhan soal yang masih berada pada ranah ingatan (C1).Hasil pengkajian yang kedua diperoleh bahwa bentuk soal pilihan ganda ataupun esai belum memenuhi kriteria soal HOTS yang baik.Hal itu terbukti dari masih banyaknnya soal pilihan ganda ataupun esai yang belum menggunakan stimulus yang menarik dan kontekstual, mengukur kemampuan kognitif level analisis, evaluasi, maupun mencipta serta belum mengandung jawaban yang tersirat.

KATA KUNCI: Higher Order Thinking Skills (HOTS); Kemampuan Guru; Soal Tes
\end{abstract}

\section{ABILITY OF INDONESIAN TEACHERS IN MAKING TEST BASED HOTS (HIGHER ORDER} THINKING SKILLS) IN JUNIOR HIGH SCHOOL DISTRICT KARANGNUNGGAL

\begin{abstract}
This research is aimed to describe (1) the ability of Bahasa Indonesia teachers to construct the questions based on HOTS for Junior High School students in Karangnunggal district Tasikmalaya and (2) the analysis of examination questions that are made by Bahasa Indonesia teachers considering the criteria of HOTS. This research was conducted at 3 Junior High School in Karangnunggal district by using qualytative descriptive method. The data source in this research is teachers of Bahasa Indonesia which amount 7 teachers. The data source are 2 teachers from SMPN 1 Karangnunggal, 2 teachers from SMPN 3 Karangnunggal, and 3 teachers from SMP IT Karangnunggal. The data gained are essay questions and multiple choice questions which are made by each respondent. The aquisition of the data in this research is using test. Those datas are examined by using descriptive analysis technique. The result of first assesment is that the ability of Bahasa Indonesia teachers to construct the quesrions based on HOTS in essay and multiple choice form is skill low. That statment is proven from the whole numbers of questions that is in memory domain (C1). The second assesment results that the assay and multiple choice from have not fulfilled the criteria of a good HOTS questions. That statment is proven from the essay and multiple choice questions that are still lack of interesting and contextual stimulants, measure that analysis level, evaluation level, and creating level of cognitif ability and also have not contained implicit answer.
\end{abstract}

KEYWORDS: Higher Order Thinking Skills (HOTS); Teacher's Ability; Test Question.

\begin{tabular}{llll}
\hline Diterima: & Direvisi: & Disetujui: & Dipublikasi: \\
$19-12-2019$ & $17-03-2020$ & $10-03-2020$ & $31-03-2020$
\end{tabular}


Pustaka : Chandra, D., \& Heyadi, D. (2020). KEMAMPUAN GURU BAHASA INDONESIA DALAM MEMBUAT SOAL TES BERBASIS HOTS (HIGHER ORDER THINKING SKILLS) DI SMP SEKECMATAN KARANGNUNGGAL. Fon: Jurnal Pendidikan Bahasa dan Sastra Indonesia, 16(1), 22-28.

DOI : https://doi.org/10.25134/fjpbsi.v16i1.2338

\section{PENDAHULUAN}

Berbicara mengenai pendidikan dan pembelajaran tidak akan lepas dari peran seseorang yang profesional. Profesionalisme yang dimaksud di atas adalah sebuah profesi. Menurut Ali, (2004) Profesionalisme merupakan paham yang mengajarkan bahwa setiap pekerjaan harus dilakukan oleh orang yang profesional.Orang yang professional itu sendiri adalah orang yang memiliki profesi. Salah satu orang yang memiliki profesi tersebut adalah guru.

Guru adalah salah satu komponen penting dalam proses pembelajaran. Selain sebagai fasilitator bagi peserta didik, guru juga berperan sebagai evaluator.Menyandang peran sebagai evaluator maka salah satu kemampuan yang harus dimiliki oleh seorang guru adalah membuat dan mengembangkan alat evaluasi.Arikunto (2013, Hlm. 3) menjelaskan,"Evaluation adalah penilaian yang dalam bahasa Indonesia berarti menilai (tetapi dilakukan dengan mengukur terlebih dahulu)". Sementara itu Mulyasa (2011) mendefinisikan bahwa evaluasi atau penilaian merupakan aspek pembelajaran yang paling kompleks, karena melibatkan banyak latar belakang dan hubungan, serta variabel lain yang mempunyai arti apabila berhubungan dengan konteks yang hampir tidak mungkin dapat dipisahkan dengan setiap segi penilaian.Berdasarkan pada penjelasan tersebut dapat disimpulkan bahwa sebelum dilakukan penilaian harus ada pengukuran terlebih dahulu.Sesuatu yang hendak diukur tentunya terkait proses pembelajaran yang telah dilalui peserta didik. Dengan adanya evaluasi yang didahului oleh pengukuran akan terlihat sejauh mana pencapaian peserta didik tentang pembelajaran yang telah dilaksanakan. Hasilnya bisa saja meningkat atau bahkan bisa saja menurun.Menurut (Awaliyah 2018) bahwa dalam meningkatkan kemampuan siswa dalam memecahkan masalah memerlukan keterampilan dalam menganalisis, mengevaluasi, dan mencipta atau yang sering disebut dengan keterampilan berpikir tingkat tinggi. Semua itu bisa didapat melalui evaluasi. Dalam melakukan evaluasi guru membutuhkan sebuah alat yang disebut dengan instrumen.

Instrumen evaluasi merupakan alat yang digunakan untuk mengukur sejauh mana peserta didik menangkap pelajaran yang telah disampaikan guru.Dalam praktiknya di sekolah-sekolah, alat evaluasi yang digunakan untuk mengukur hasil belajar peserta didik adalah instrumen tes. Berkenaan dengan hal tersebut salah satu fungsi tes yaitu digunakan untuk mengukur kemampuan peserta didik dan keberhasilan proses belajar mengajar di kelas. Berkaitan dengan hal tersebut kemampuan siswa yang hendak diukur salah satunya yaitun kemampuan kognitif. Berikut di bawah ini gambaran Level Kognitif Taksonomi Bloom. (Nugroho, 2018, Hlm. 20)

Mengacu pada diagram di atas maka dapat dibaca bahwa level kognitif yang paling rendah dimulai dari ingatan, pemahaman, aplikasi, analisis, evaluasi, dan yang paling tinggi adalah mencipta. Namun pada kenyataannya di lapangan tidak seperti itu, guru belum mampu mebuat soal tes yang baik.Hal ini diperkuat dengan penelitian yang dilakukan oleh (Hariyana dkk., 2015) 
menjelaskan bahwa sebagian besar guru masih malas dalam membuat soal.Kebanyakan guru lebih suka mengambil soal dari internet dibandingkan dengan membuat soal sendiri.Selain itu (Lestari dkk., 2016) menyatakan bahwa pada dasarnya guru sering mendengar kemampuan berpikir tingkat tinggi, namun dalam pembuatan soal guru lebih suka mengembangkan kemampuan berpikir tingkat rendah atau LOTS. Hal itu dikarenakan guru hanya menyesuaikan dengan indikator pembelajaran yang nantinya dijadikan soal. Padahal di sekolah-sekolah buku pelajaran sudah mengajak peserta didik untuk mampu berpikir kritis serta kreatif.

Berkenaan dengan hal di atas, faktor-faktor tersebut menjadi latar belakang penulis untuk melakukan penelitian ini. Penelitian ini bertujun untuk mendeskripsikan kemampuan guru dalam membuat soal berbasis HOTS dan menganalisis kesesuaian soal berdasarkan kriteria HOTS yang baik.

\section{METODE}

Metode yang digunakan dalam penelitian ini yaitu metode deksriptif kualitatif. Menurut Heryadi (2010,hlm.42), "Metode penelitian deskriptif adalah metode penelitian yang digunakan untuk menggambarkan suatu objek yang ada dan terjadi saat ini dalam rangka menjawab suatu permaslahan penelitian".

Hal ini diperkuat juga oleh pendapat Sukardi (2013) yang menyatakan bahwa tujuan penelitian deskriptif yaitu untuk menggambarkan karakteristik subjek atau objek penelitian dengan tepat tanpa adanya rekayasa.Selain itu dalam pelaporannya, penelitian bentuk ini dapat dilaporkan secara sederhana dan tidak menggunakan teknik statistik yang rumit.

Alasan metode deskriptif kualitatif dipilih dalam penelitian ini karena penelitian ini berusaha untuk mendeskripsikan atau menggambarkan secara detail tentang tingkatan soal-soal tes dan karakteristik soal tersebut jika dilihat berdasarkan kriteria Higher Order Thinking Skills (HOTS) yang dibuat guru mata pelajaran Bahasa Indonesia di Sekolah Menengah Pertama (SMP) yang berada di wilayah Kecamatan Karangnunggal Kabupaten Tasikmalaya tahun ajaran 2018/2019. Jumlah responden secara keseluruhan berjumlah 7 orang. Teknik pengumpulan data dan instrumen yang digunakan dalam penelitian ini yaitu instrumen tes. Kemudian prosedur penelitian meliputi tahap penyusunan instrumen, pengumpulan data, deskripsi data, analisis data, pembuatan simpulan.

\section{HASIL DAN PEMBAHASAN \\ Kemampuan Guru dalam Membuat Soal HOTS}

Setelah dilakukan analisis dapat diperoleh hasil bahwa dari keseluruhan jumlah responden yang berjumlah 7 orang, ternyata kemampuan guru dalam membuat soal berbasis HOTS masih rendah, baik soal bentuk esai ataupun pilihan ganda. Hal tersebut terbukti karena masih banyaknya soal yang belum mengukur kemampuan siswa dalam hal analisis, evaluasi, maupun mencipta. Berikut ini disajikan beberapa contoh soal esai dan pilihan ganda yang belum mengukur kemampuan $\mathrm{C} 4, \mathrm{C} 5$, dan $\mathrm{C} 6$.

\section{2: Malioboro terletak di kota?}

3: Dimana sajakah destinasi wisata yang terdapat di Yogyakarta?

8: Fasilitas apa saja yang ada di Malioboro?

1: Siapakah Catur Wulan....

a. Gadis desa

b. Gadis yang cantik 


\section{c. Gadis kota \\ d. Gadis kampung}

7: Siapakah yang menolong catur wulan....

a. Pangeran

b. Ibu

c. Kunang-kunang

d. Dewi Bulan

Beberapa contoh soal di atas diambil dari beberapa responden. Setelah dianalisis dan dilakukan pembahasan ternyata soal-soal tersebut belum mengukur kemampuan siswa dalam hal analisis, evaluasi, dan mencipta. Hal tersebut terjadi karena soal-soal di atas masuk pada ranah kelompok soal $\mathrm{C} 1$. Ranah soal C1 memiliki ciri-ciri yaitu mengukur kemampuan ingatan saja.

\section{Bentuk Soal yang Dibuat Guru Berdasarkan Kriteria HOTS.}

Untuk mengetahui apakah soal uraian atau pilihan ganda yang telah dibuat oleh guru sudah masuk kategori jenis soal HOTS atau belum maka digunakan instrumen telaah soal HOTS untuk bentuk soal uraian/pilihan ganda seperti pada tabel 4.4.berikut.

Tabel 1. Instrumen Telaah Soal HOTS Uraian/Pilihan Ganda

\begin{tabular}{|c|c|}
\hline No & Aspek yang Ditelaah \\
\hline 1 & $\begin{array}{l}\text { Soal menggunakan stimulus yang } \\
\text { menarik (baru, mendorong peserta } \\
\text { didik untuk membaca) }\end{array}$ \\
\hline 2 & $\begin{array}{l}\text { Soal menggunakan stimulus yang } \\
\text { kontekstual (gambar/grafik, } \\
\text { visualisasi, dll, sesuai dengan dunia } \\
\text { nyata) }\end{array}$ \\
\hline 3 & $\begin{array}{l}\text { Soal mengukur level kognitif penalaran } \\
\text { (menganalisis, mengevaluasi, dan } \\
\text { mencipta) yang dalam penyelesaiannya } \\
\text { dicirkan dengan salah satu atau lebih } \\
\text { tahapan proses berpikir berikut: } \\
\text { - transfer satu konsep ke konsep } \\
\text { lainnya } \\
\text { - memproses dan menerapkan } \\
\text { informasi }\end{array}$ \\
\hline
\end{tabular}

\begin{tabular}{|c|c|}
\hline & $\begin{array}{l}\text { - mencari kaitan dari berbagai } \\
\text { informasi yang berbeda-beda } \\
\text { - menggunakan informasi untuk } \\
\text { menyelesaikan masalah } \\
\text { menelaah ide dan informasi secara } \\
\text { kritis }\end{array}$ \\
\hline 4 & Jawaban tersirat pada stimulus \\
\hline
\end{tabular}

Keterangan: (\#)khusus untuk bahasa Indonesia bisa menggunakan teks fiksi, karangan, dan sejenisnya. (I Wayan.2017)

Instrumen $\mathrm{di}$ tabel $4.4 \mathrm{di}$ atas menunjukkan elemen-elemen yang harus diperhatikan dalam menganalisis soal HOTS. Selanjutnya dijabarkan dan dijelaskan hasil analisis soal uraian dan pilihan ganda berdasarkan elemen-elemen telaah soal HOTS.

\section{a. Soal Menggunakan Stimulus Menarik dan Kontekstual \\ Secara keseluruhan jumlah} responden berjumlah tujuh orang. Masingmasing responden membuat soal tes bentuk esai dan pilihan ganda sebanyak 10 butir soal. Mengacu pada hasil analisis dan pembahasan yang berdasarkan pada kriteria HOTS di atas dapat diperoleh bahwa secara umum ketujuh responden yang membuat soal tes esai dan pilihan ganda belum menggunakan stimulus yang menarik dan kontekstual. Seperti contoh:

\section{2: Malioboro terletak di kota?}

10: Akhir cerita fantasi "Legenda Putri Bulan" kecuali....
a. Happy
b. Wulan dan pangeran Rangga bisa bertemu/kenalan
c. Wulan menjadi perempuan paling cantik
d. Kecantikan wulan menyebar

Butir soal nomor 2 tidak terdapat stimulus yang menarik, baru, dan mendorong siswa untuk membaca terlebih dahulu. Soal tersebut tidak mengandung perangsang pertanyaan artinya hanya 
terdiri dari soal saja. Begitupun dengan butir soal nomor 10 hanya terdiri dari pokok soal saja yang langsung menanyakan ending dari cerita Legenda Putri Bulan. Berbeda halnya dengan contoh soal berikut ini.

Sebagai salah satu destinasi wisata, pinggiran jalan Malioboro dibuat cukup lebar untuk para pejalan kaki. Terdapat berbagai fasilitas seperti bangku, halte bus, dan tempat persinggahan bagi para pejalan kaki untuk sekedar duduk menikmati suasana kota Yogyakarta. Selain itu banyak pedagang kaki lima yang menjual cinderamata khas Yogyakarta dan juga berbagai macam kuliner untuk dinikmati para wisatawan.

Dari penggalan teks di atas, gambarkan kembali keindahan jalan Malioboro dengan bahasa sendiri!

Soal tersebut memiliki stimulus berupa penggalan paragraf dari teks yang berjudul Malioboro.Stimulus tersebut dijadikan dasar pertanyaan tentang penggambaran kembali keindahan jalan Malioboro.

\section{b. Mengukur Kemampuan Kognitif} Analisis, Evaluasi, dan Mencipta.

Selain aspek stimulus yang menarik dan kontekstual, aspek lain yang harus diperhatikan dalam menyusun soal HOTS yaitu soal-soal harus mengukur kemampuan level kognitif penalaran yang meliputi aspek menganalisis, mengevaluasi, dan mencipta. Menurut Anderson dan Krathwohl dalam Nugroho (2018, Hlm. 20), "Soal-soal HOTS mempunyai ciri yang khas yaitu mengukur kemampuan penalaran siswa dalam ranah menganalisis, mengevaluasi, dan mencipta".

Berdasarkan analisis data, ternyata masih banyak soal esai maupun pilihan ganda yang dibuat oleh masing-masing responden belum mengukur tingkat kognitif ranah menganalisis, mengevaluasi, dan mencipta.Sebagai contoh penulis sajikan contoh soal esai dan pilihan ganda yang dibuat oleh setiap responden.

Contoh:

\section{2:Malioboro terletak di kota?}

5:Siapa saja pengunjung atau
wisatawan yang datang ke
Malioboro?

\section{(Pilihan Ganda)}

1: Dalam struktur teks cerita fantasi pengenalan nama tokoh, latar dan konflik merupakan bagian dari....
a. Identifikasi
b. Orientasi
c. Komplikasi
d. Resolusi

6: Sungguh cantik malam ini Ujar wulan yang tengah takjub meilhat alam tersebut. Gaya bahasa apa yang terdapat pada kata "Sungguh cantik malam in"....
a. Ironi
b. Personifikasi
c. Metafora
d. Hiperbla

Soal-soal di atas belum mengukur kemampuan kognitif siswa dalam ranah analisis, evaluasi, maupun mencipta karena soal tersebut hanya berada pada ranah ranah $\mathrm{C} 1$ dan $\mathrm{C} 2$. Artinya dalam menjawab soal-soal tersebut siswa tidak melibatkan tahap-tahap seperti mentransfer satu konsep ke konsep lain, memproses dan menerapkan informasi, mencari kaitan dari berbagai informasi yang berbeda-beda, menggunakan informasi untuk menyelesaikan masalah, serta menelaah ide dan informasi secara kritis. 


\section{c. Mengandung Jawaban Tersirat}

Terkait dengan aspek-aspek yang harus diperhatikan saat menyusun soal HOTS, salah satu aspek yang tidak bisa dilupakan adalah jawaban soal harus tersirat pada stimulus. Yang dimaksud dengan tersirat yaitu terkandung (tersembunyi) di dalam stimulus yang disajikan (Widana, 2017). Mengingat aspek tersebut juga sangat penting, berikut ini akan dibahas lebih dalam mengenai soal-soal yang dibuat setiap responden ditinjau dari segi jawaban yang tersirat pada stimulus.seerti halnya contoh soal di bawah ini.

1. Kota yang menjadi ikon utama wisata Yogyakarta adalah?

2. Malioboro terletak di kota?

1: Siapakah catur wulan....

a. Gadis desa

b. Gadis yang cantik

c. Gadis kota

d. Gadis kampong

2: Kenapa selalu memakai cadar....

a. Supaya cantik

b. Menutupi mukanya yang jelek

c. Supaya tidak terlihat orang lain

d. Agar tidak kepanasan

Soal-soal di atas belumlah mengandung jawaban tersirat atau tersembunyi dalam stimulus. Hal tersebut dikarenakan jawaban yang dicari sudah tersurat secara jelas dan eksplisit pada teks yang telah disediakan.

Jadi berdasarkan kesimpulan secara umum bahwa soal-soal yang dibuat guru baik esai maupun pilihan ganda belum memenuhi kriteria soal HOTS. Hal tersebut terbukti dari masih banyaknya soal yang belum memenuhi elemen-elemen kriteria soal HOTS.

\section{KESIMPULAN}

Berdasarkan tujuan penelitian, penulis telah melaksanakan penelitian di tiga sekolah tepatnya di kecamatan Karangnunggal.Terkait jenjang sekolah yang dijadikan tempat penelitian yaitu SMP Negeri 1 Karangnunggal, SMP Negeri 3 Karangnunggal dan SMP IT Karangnunggal. Penelitian yang penulis laksanakan sifatnya deskriptif dengan mangacu pada tujuan penelitian yaitu untuk mengetahui kemampuan guru mata pelajaran Bahasa Indonesi dalam membuat soal tes dan mengetahui soal tes yang dibuat guru jika ditinjau dari kriteria HOTS. Jumlah responden dari SMP Negeri 1 Karangnunggal sebanyak 2 orang, dari SMP.

\section{DAFTAR PUSTAKA}

Arikunto, Suharsimi. (2010). Prosedur Penelitian: Suatu Pendekatan Praktik. Jakarta: Rineka Cipta. , (2013). Dasar-Dasar Evaluasi Pendidikan Edisi 2. Jakarta: Bumi Aksara.

Awaliyah, Siti. (2018). Penyusunan Soal HOTS Bagi Guru PPKN dan IPS Sekolah Menengah Pertama. Jurnal Praksis dan Dedikasi Sosial. Vol 1 No 1 April 2018.

Heryadi, Dedi. (2010). Metode Penelitian Pendidikan Bahasa. Bandung: Pustaka Billah.

Lestari, Angi, dkk. (2016). Pengembangan Soal Tes Berbasis HOTS Pada Modl Pembelajaran Latihan Di Sekolah Dasar. UPI Tasikmalaya: Program S-1 PGSD.

Muhson, Ali. (2004). Meningkatkan Profesionalisme Guru.Jurnal Ekonomi dan Pendidikan.Vol (2) 1 Agustus.

Mulyasa, E. (2011).Menjadi Guru Profesional. (Mencipatkan Pembelajaran Kreatif dan Menyenangkan).Bandung: $\quad$ PT Remaja Rosdakarya. 
Nugroho, M.Arifin. 2018. HOTS (Higher Order Thinking Skills).Jakarta:PT Gramedia.

Shidiq, Ari Syahidul, dkk. 2015. Analisis Higher Order Thinking Skills (HOTS) Menggunakan Instrumen Two-Tier Multiple Choice Pada Materi Kelarutan dan Hasil Kali Kelarutan untuk Siswa Kelas XI SMA $N$ Surakarta. Prosiding Seminar Pendidikan Sains (SNPS). UNS.
Sukardi. 2013. Metode Penelitian Pendidikan (Kompetensi dan Praktiknya). Jakarta: Bumi Aksara.

Widana, I Wayan.2017.Modul Penyusunan Soal Higher Order Thinking Skills (HOTS).Jakarta:Direktorat

Pembinaan SMA Direktorat Jendral Penddikan Dasar dan Menengah Depdikbud. 